\title{
GENETIC GAINS OF MILK YIELD AND MILK COMPOSITION AS REALIZED RESPONSE TO DAIRY COW SELECTION IN BBPTU-HPT BATURRADEN, INDONESIA
}

\author{
A. P. Rahayu*, S. Johari and E. Kurnianto \\ Faculty of Animal and Agricultural Sciences, Diponegoro University, \\ Tembalang Campus, Semarang 50275 - Indonesia \\ *Permanent address: Animal Husbandry and Fisheries Center of Semarang Regency, \\ Jl. Letjend Suprapto 7, Ungaran 50514 - Indonesia \\ CorrespondingE-mail: kurniantoedy17@gmail.com
}

Received April 03, 2015; Accepted May 26, 2015

\begin{abstract}
ABSTRAK
Penelitian ini bertujuan untuk menaksir heritabilitas, mengetahui pengaruh seleksi sapi perah betina, dan menganalisis kemajuan genetik pada produksi dan komposisi susu di Balai Besar Perbibitan Ternak Unggul dan Hijauan Pakan Ternak (BBPTU-HPT) Baturraden, Indonesia. Penelitian menggunakan 221 catatan laktasi pertama periode 2006-2014. Heritabilitas ditaksir dengan korelasi saudara tiri sebapak. Perbandingan antara rataan penampilan pada populasi anak $(\overline{\mathrm{A}})$ dengan populasi awal induk sebelum seleksi $(\overline{\mathrm{P}})$ dilakukan dengan menggunakan uji Z. Kemajuan genetik per tahun merupakan kemajuan genetik per generasi (selisih antara $\bar{A}$ dan $\bar{P}$ ) dibagi dengan interval generasi. Hasil penelitian menunjukkan heritabilitas kadar lemak, produksi lemak, kadar protein dan produksi protein susu masing-masing 0,$46 ; 0,30 ; 0,28$ dan 0,17 . Produksi susu generasi ke-2 $\left(\mathrm{G}_{2}\right)$ yang nyata lebih tinggi $(\mathrm{P}=0,025)$ dari generasi pertama $\left(\mathrm{G}_{1}\right)$ menghasilkan kadar lemak yang sangat nyata lebih rendah $(\mathrm{P}=0,004)$. Kemajuan genetik untuk produksi, kadar lemak dan protein susu masing-masing 9,76 kg; $-0,04 \%$ dan $-0,01 \%$ per tahun. Kesimpulan penelitian adalah seleksi yang hanya diarahkan untuk produksi susu berdampak negatif terhadap kadar lemak dan protein susu. Seleksi dapat dilakukan berdasarkan produksi lemak susu untuk mencegah penurunan kadar lemak susu. Pengaruh negatif interaksi genetik-lingkungan menyebabkan kemajuan genetik menjadi lambat akibat sapi impor membutuhkan waktu untuk beradaptasi dengan lingkungan lokal.
\end{abstract}

Kata kunci: heritabilitas, produksi susu, komposisi susu, respon seleksi, kemajuan genetik

\begin{abstract}
The aims of this study were to estimate the heritabilities, examine the effects of dairy female selection and calculate the genetic gains on milk yield and milk composition in Baturraden Dairy Cattle Breeding and Forage Centre (Balai Besar Perbibitan Ternak Unggul dan Hijauan Pakan Ternak / BBPTU-HPT Baturraden), Indonesia. The first lactation records of 221 dairy cows from 2006 to 2014 were used. Heritabilities were estimated by paternal half-sib correlation. Comparison of average performances between daughter population $(\overline{\mathrm{A}})$ and initial dam population before selection $(\overline{\mathrm{P}})$ were conducted by Z-test. Annual genetic gain was calculated as genetic gain per generation (the differences between $\bar{A}$ dan $\bar{P}$ ) divided by generation interval. Heritabilities for milk fat percentage (FP), milk fat yield (FY), milk protein percentage (PP) and milk protein yield (PY) were $0.46,0.30,0.28$ and 0.17 , respectively. A significant increase $(\mathrm{P}=0.025)$ in the total milk yield $(\mathrm{TMY})$ from the first generation $\left(\mathrm{G}_{1}\right)$ to the second generation $\left(\mathrm{G}_{2}\right)$ resulted in a high significant decrease in the FP $(\mathrm{P}=0.004)$. Genetic gains of TMY, FP and PP were $9.76 \mathrm{~kg},-0.04 \%$ and $-0.01 \%$ per year, respectively. It is concluded that selection for higher TMY only negatively affect FP and PP. Selection can be applied based on FY to
\end{abstract}


avoid the decrease of FP. Negative effects of genetic-environmental interaction resulted in slower genetic gain because the imported cows needed time to adapt to the local environment.

Keywords: heritability, milk yield, milk composition, selection response, genetic gain

\section{INTRODUCTION}

Dairy cow population in Indonesia increased only in small quantities from year to year, even decreased by $27 \%$ in 2013 . National dairy cow population from 2009 to 2014 were 474,701; 488,448; 597,213; 611,939; 636,064 (Ditjen PKH, 2013); 444,000 and 483,000 heads (BPS, 2015), respectively. The needs of domestic milk reached 3.2 million tons per year, but domestic milk only able to supply about $\pm 25 \%$, while about $\pm 75 \%$ is imported. Therefore, it is necessary to improve dairy cattle productivity, one of which with genetic quality improvement through selection to provide more permanent impact on its productivity.

Baturraden Dairy Cattle Breeding and Forage Centre (Balai Besar Perbibitan Ternak Unggul dan Hijauan Pakan Ternak / BBPTUHPT Baturraden) has been doing the dairy female selection program. Kurnianto (2009) described selection as an effort to select animal that are considered to be preserved as a replacement for the next generations and cull the animal that are considered unfavorable by specific criteria. The increase of phenotypic mean after selection compared to the previous generation before selection is called a selection response (Santosa et al., 2011). One of the important factors for the successful selection is heritability. Heritability of milk yield in BBPTU-HPT Baturraden has been widely studied (Kamayanti et al., 2006; Karnaen and Arifin, 2009; Kurniawati et al., 2013), but it was still lack of study on heritabilities of milk composition (Muladno and Astuti, 1985). These values are important because milk composition genetic improvement is also required. Previous studies (Hindratiningrum, 2008; Santosa et al., 2011) have predicted milk yield selection response, but the realized response (also known as genetic gain) and its effect on milk composition as correlated responses have not been studied yet, because it only can be obtained after data of progenies are available. This study was conducted to estimate the heritabilities, examine the effects of dairy female selection, and calculate the genetic gains on milk yield and milk composition in BBPTU-HPT Baturraden.

\section{MATERIALS AND METHODS}

\section{Location and Materials}

This study was conducted from September to October 2014 in BBPTU-HPT Baturraden, Purwokerto, Central Java, Indonesia. The first lactation daily records of the $0^{\text {th }}$ generation $\left(\mathrm{G}_{0}\right)$, $1^{\text {st }}$ generation $\left(\mathrm{G}_{1}\right)$ and 2 nd generation $\left(\mathrm{G}_{2}\right)$ from 2006 to 2014, selection records, and catalogs were used. The criteria of used data were date of birth, records for both dam and daughters (except for culled cows) and 185-425 days of lactation length (LL).

The $\mathrm{G}_{0}$ were cows imported from New Zealand (NZ) in the year 2005. There were 74 cows of $\mathrm{G}_{0}$ that met the criteria (61 selected dams, 13 culled cows) and 106 data of their daughters available $\left(G_{1}\right)$. From $G_{1}, 59$ cows could not further analyzed because they have no daughter, their daughters were sold as heifers or did not meet the criteria. There were 47 cows $\left(\mathrm{G}_{1}{ }^{\prime}\right)$ that met the criteria (38 selected dams, 9 culled cows) and 41 data of their daughters available $\left(\mathrm{G}_{2}\right)$. Total amount of data was 221 .

\section{Parameters Measured}

Studied parameters were the averages of corrected total milk yield (TMY), milk fat percentage (FP), milk fat yield (FY = FP x TMY), milk protein percentage (PP) and milk protein yield (PY = PP x TMY).

\section{Data Analysis}

Data were corrected for LL and mature equivalent using local correction factor by Santosa et al. (2014). Heritabilities were estimated by unbalanced design of paternal halfsib correlation method using one-way analysis of variance (one-way ANOVA) based on Kurnianto (2009). Performances between the daughters of selected dam and the initial dam population were compared by unpaired Z-test using SPSS 20 . The influence of birth year on TMY was analyzed using one-way ANOVA. Simulations were performed for selection based on TMY compared to selection based on FP with $10 \%$ to $90 \%(10 \%$ of interval) proportion of selected dams.

The formulas for genetic gains (predicted and realized), annual genetic gain and selection 
effectivity were respectively based on Kurnianto (2009), Berry et al. (2011) and Hindratiningrum (2008) as follows:

$$
\begin{aligned}
& \text { Predicted Genetic Gain, } \Delta \mathrm{G}=\mathrm{h}^{2}\left(\mathrm{P}_{\mathrm{s}}-\mathrm{P}\right) \\
& \text { Realized Genetic Gain, } \Delta \mathrm{G}=\mathrm{A}-\mathrm{P} \\
& \text { Annual Genetic Gain, } \Delta \mathrm{G} / \text { year }=\frac{\Delta \mathrm{G}}{\mathrm{L}} \\
& \text { Selection Effectivity, Es }=\frac{\Delta \mathrm{G}}{\overline{\mathrm{P}}} \times 100 \% \\
& \Delta \mathrm{G}=\text { selection response or genetic gain per } \\
& \overline{\mathrm{P}}_{\mathrm{s}}=\text { average performance of the selected dam } \\
& \text { population } \\
& \overline{\mathrm{P}}=\text { average performance of the initial dam } \\
& \text { population (before selection) } \\
& \overline{\mathrm{A}}=\text { average performance of the daughter } \\
& \text { population } \\
& \mathrm{L}=\text { generation interval (average age of dams }
\end{aligned}
$$

\section{RESULTS AND DISCUSSION}

\section{Estimated Heritability $\left(h^{2}\right)$}

Estimated heritability for TMY, FP, PP, FY and PY were $0.20 \pm 0.26,0.46 \pm 0.33,0.28 \pm 0.27$, $0.30 \pm 0.29$ and $0.17 \pm 0.25$, respectively (Table 1 ). The heritability of TMY was lower than those reported by Harris et al. (2006) in NZ (0.308). Ojango and Pollott (2001) reported that heritability of TMY from temperate breeds kept in the tropics were lower than those from similar breeds kept in temperate countries. Lower heritability lead to lower selection accuracy because selection accuracy is equal to square root of heritability. Heritabilities of FY and PY were within the range reported ( 0.30 to 0.35 for FY and 0.15 to 0.40 for PY) by Cassell (2009). In the other hand, the heritability of PP was lower than generally (0.50). Toghiani (2012) also found lower heritabilities of FP and PP in HolsteinFriesian (HF) cows in Iran (0.23 respectively). Heritability may vary depending on the observation years, breeds, estimation methods, origin and quantity of data (Kurnianto, 2009). Large quantity of data is recommended to minimize standard error (Cassell, 2009).

\section{Total Milk Yield}

Selection was done twice a year based on test day analysis. Selected dams belongs to group of grade A $(>6,000 \mathrm{~kg}), \mathrm{B}(>5,000-6,000 \mathrm{~kg})$ or C
Table 1. Estimated Heritability of Milk Yield and Milk Composition

\begin{tabular}{lccl}
\hline Parameter & Heritability* & $\begin{array}{c}\text { Standard } \\
\text { Error }\end{array}$ & Category \\
\hline TMY & 0.20 & 0.26 & moderate \\
FP & 0.46 & 0.33 & high \\
PP & 0.28 & 0.27 & moderate \\
FY & 0.30 & 0.29 & moderate \\
PY & 0.17 & 0.25 & moderate \\
\hline
\end{tabular}

$* 0.00$ to $0.15=$ lowly heritable; $>0.15$ to $0.30=$ moderately heritable; 0.30 to $1.00=$ highly heritable (Kurnianto, 2009). TMY= total milk yield, FP = milk fat percentage; $\mathrm{PP}=$ milk protein percentage; $\mathrm{FY}=$ milk fat yield; $\mathrm{PY}=$ milk protein yield

$(>4,000-5,000 \mathrm{~kg})$ per lactation. Estimated breeding value (EBV) were sorted from the highest. Limited to the data used in this study, the overall percentage of culled cows was $18.18 \%$. This is still below the ideal culling rate (from 20 to $30 \%$ ) suggested by Radke (2000).

TMY of $\mathrm{G}_{1}(4,655.78 \pm 848.10 \mathrm{~kg})$ was significantly lower $(\mathrm{P}=0.038)$ than $\mathrm{G}_{0}$ $(4,927.83 \pm 779.02 \mathrm{~kg})$, as presented in Table 2 . This was not in line with expectations (Table 3 ), it was possible due to the impact of $\mathrm{G}_{0}$ 's native environment. $\mathrm{G}_{0}$ were imported as heifers, about 5 to 11 months before their first calving. Most dairy farms in NZ are seasonal and grass-based systems. After being imported, the cattle took adaptation period to the local environtment. It was indicated from their TMY. According to certificates, TMY of $\mathrm{G}_{0}$ dams was $5,824.25 \mathrm{~kg}$. $\mathrm{G}_{0}$ should be near this, but in fact theirs only $4,927.83 \mathrm{~kg}$. Maintenance in $\mathrm{NZ}$ supported the growth of $\mathrm{G}_{0}$, including body weight and udder affecting TMY. First-lactation TMY increased as prepubertal daily gains increased up to $799 \mathrm{~g} / \mathrm{d}$ and body weight at calving increased up to $550 \mathrm{~kg}$ (Zanton and Heinrichs, 2005). Udder growth has begun since \pm 30 days after conception and influence production capabilities with positive correlation value of about 0.32 (Sawa et al., 2013). Thus, although TMY of $\mathrm{G}_{0}$ was lower than its potential, there were beneficial effects from $\mathrm{NZ}$ environment causing it was still higher than $\mathrm{G}_{1}$.

As daughters of selected dams, $\mathrm{G}_{1}$ have good genetic potential, but it could not be maximally 
expressed because of the genetic-environmental (GxE) interaction (differences of the genotypic response in different environments). Kiplagat et al. (2012) stated that favorable genes in some environments may become unfavorable under other environments. Some alleles may only be expressed in some specific environment due to change in some gene regulations depending on the environment (climate, feed, management, housing, etc). The temperatures in NZ are 10.71 to $17.62{ }^{\circ} \mathrm{C}$ (Lal et al., 2013) whereas Baturraden are 18 to $30{ }^{\circ} \mathrm{C}$ with humidity of 70 to $80 \%$. HF cows will be comfortable at temperature humidity index (THI) $<72$. In dry season, Baturraden could reach THI of 73 to 83 , causing mild to moderate stress. It resulted in lower consumption and metabolism rates causing decreased TMY (Gantner et al., 2011). Many other studies also showed GxE interaction (Mirkena et al., 2010; Bohlouli and Alijani, 2012). Beside the GxE interaction, lower TMY of $G_{1}$ was because the sires of $G_{1}(80 \%$ local frozen semen) had lower average EBV $(+258 \mathrm{~kg})$ than the sires of $\mathrm{G}_{0}$ (imported elite bulls) whose average EBV was $+1,217.73 \mathrm{~kg}$ (according to certificates). Sire with higher EBV inherit higher superiority (Kurnianto, 2009).

Positive selection response appeared in $\mathrm{G}_{2}$ (Table 3). TMY of $\mathrm{G}_{2}(5,004.22 \pm 1,044 \mathrm{~kg})$ was significantly higher $(\mathrm{P}=0.025)$ than $\mathrm{G}_{1}{ }^{\prime}$ $(4,535.58 \pm 882.70 \mathrm{~kg})$, as presented in Table 2. It was because the cows have been adapted to the environment. $\mathrm{G}_{1}$ born in 2006-2007 had lower TMY than $\mathrm{G}_{1}$ born in the year thereafter (Table 4). In that period, $\mathrm{G}_{0}$ had just imported so that some energy were used for adaptation. As a result, when pregnant, nutrition to support foetus $\left(\mathrm{G}_{1}\right)$ growth was less than optimal. Unsignificant influence of birth year in 2008-2011 indicates that the negative effects of GxE interaction have been eliminated, so that potential genetic of $G_{2}$ inherited from $G_{0}$ and $G_{1}$ could be better expressed. As stated by Ayalew et al. (2003) and Mirkena et al. (2010), the degree of adaptability affected productivity.

\section{Milk Composition}

Selection of a trait may affect other traits. It

Table 2. Total Milk Yield (kg), Milk Fat Percentage (\%) and Milk Protein Percentage (\%) Between Two Generations

\begin{tabular}{lccc}
\hline \multicolumn{1}{c}{ Parameter } & \multicolumn{2}{c}{ Generation } & Significance \\
\hline $\mathrm{G}_{0}$ vs G $_{1}$ & $\mathrm{G}_{0}(\mathrm{n}=74)$ & $\mathrm{G}_{1}(\mathrm{n}=106)$ & \\
TMY & $4,927.83 \pm 779.02^{\mathrm{a}}$ & $4,655.78 \pm 848.10^{\mathrm{b}}$ & 0.038 \\
$\mathrm{FP}$ & $4.68 \pm 0.56$ & $4.76 \pm 0.553$ & 0.358 \\
$\mathrm{PP}$ & $3.01 \pm 0.16$ & $3.00 \pm 0.12$ & 0.670 \\
& & & \\
$\mathrm{G}_{1}{ }^{\prime}$ vs $\mathrm{G}_{2}$ & $\mathrm{G}_{1}{ }^{\prime}(\mathrm{n}=47)$ & $\mathrm{G}_{2}(\mathrm{n}=41)$ & \\
TMY & $4,535.58 \pm 882.70^{\mathrm{b}}$ & $5,004.22 \pm 1,044.00^{\mathrm{a}}$ & 0.025 \\
FP & $4.70 \pm 0.42^{\mathrm{a}}$ & $4.35 \pm 0.63^{\mathrm{b}}$ & 0.004 \\
PP & $2.97 \pm 0.17$ & $2.93 \pm 0.13$ & 0.231 \\
& & & \\
$\mathrm{G}_{0}$ vs G & $\mathrm{G}_{0}$ & $\mathrm{G}_{2}$ & \\
TMY & $4.927 .83 \pm 779.02$ & $5,004.22 \pm 1,044.00$ & 0.658 \\
FP & $3.08 \pm 0.56^{\mathrm{a}}$ & $4.35 \pm 0.63^{\mathrm{b}}$ & 0.009 \\
PP & & $2.93 \pm 0.13^{\mathrm{b}}$ & 0.009 \\
\hline
\end{tabular}

Means with different superscripts within same row differ significantly $(\mathrm{P}<0.05) ; \mathrm{G}_{0}=$ initial population of dams; $G_{1}=$ daughters population of selected $G_{0} ; G_{1}{ }^{\prime}=G_{1}$ that met the criteria for further analysis; $G_{2}$ $=$ daughters population of selected $\mathrm{G}_{1}, \mathrm{TMY}=$ total milk yield, $\mathrm{FP}=$ fat percentage; $\mathrm{PP}=$ protein percentage 
Table 3. Predicted and Realized Selection Response

\begin{tabular}{lrr}
\hline \multicolumn{1}{c}{ Parameters } & \multicolumn{1}{c}{$\mathrm{G}_{1}$} & \multicolumn{1}{c}{$\mathrm{G}_{2}$} \\
\hline & $\ldots \ldots \ldots \ldots \ldots \ldots \ldots \ldots \ldots \ldots \ldots \ldots \ldots \ldots \ldots$ \\
TMY of initial population of dams & $4,927.83$ & $4,535.58$ \\
TMY of selected dams & $5,184.43$ & $4,785.80$ \\
Selection differential & 256.59 & 250.22 \\
Predicted selection response & 51.32 & 50.04 \\
Expected TMY of daughter & $4,979.15$ & $4,585.63$ \\
Realized TMY of daughter & $4,655.78$ & $5,004.22$ \\
Realized response to selection & -272.05 & 468.64 \\
Differences between predicted and realized response & -323.37 & 418.59 \\
\hline
\end{tabular}

Table 4. Average of Total Milk Yield Based on the Birth Year

\begin{tabular}{cccccc}
\hline \multirow{2}{*}{ Birth Year } & \multicolumn{2}{c}{$\mathrm{G}_{1}$} & \multicolumn{2}{c}{$\mathrm{G}_{2}$} \\
\cline { 2 - 5 } \cline { 5 - 6 } & $\mathrm{n}$ & \multicolumn{2}{c}{ Milk Yield $(\mathrm{kg})$} & $\mathrm{n}$ & Milk Yield $(\mathrm{kg})$ \\
\hline 2006 & 17 & $3,868.34 \pm 613.02^{\mathrm{b}}$ & - & - \\
2007 & 32 & $4,472.41 \pm 852.24^{\mathrm{b}}$ & - & - \\
2008 & 30 & $5,037.71 \pm 665.36^{\mathrm{a}}$ & & 4 & $4,784.04 \pm 471.43$ \\
2009 & 14 & $5,081.81 \pm 636.70^{\mathrm{a}}$ & & 9 & $5,008.70 \pm 725.85$ \\
2010 & 8 & $4,915.30 \pm 879.19^{\mathrm{a}}$ & & 13 & $5,206.41 \pm 771.73$ \\
2011 & 5 & $4,839.11 \pm 1,224.30^{\mathrm{a}}$ & & 15 & $4,885.01 \pm 1,479.15$ \\
\hline
\end{tabular}

Means with different superscripts within same column differ significantly $(\mathrm{P}<0.05)$

Table 5. Genetic Gains of Milk Yield and Composition

\begin{tabular}{lccr}
\hline Parameters & $\begin{array}{c}\text { Per 2 } \\
\text { Generations }\end{array}$ & $\begin{array}{c}\text { Per } \\
\text { Generation }\end{array}$ & Per Year \\
\hline TMY (kg) & 76.39 & 38.20 & 9.76 \\
FP (\%) & -0.33 & -0.16 & -0.04 \\
PP (\%) & -0.08 & -0.04 & -0.01 \\
\hline
\end{tabular}

is presented in Table 2, FP $(4.35 \pm 0.63 \%)$ and PP $(2.93 \pm 0.13 \%)$ of $\mathrm{G}_{2}$ was significantly lower $(\mathrm{P}<0.01)$ than $\mathrm{G}_{0}(4.68 \pm 0.56 \%$ and $3.01 \pm 0.16 \%$, respectively). The FP was close to the range of $\mathrm{HF}$ cows in NZ (4.42 to $5.03 \%$ ) reported by Lopez-
Villalobos (2012). A significant increase of TMY from $G_{1}$ to $G_{2}$ resulted in a significant decrease in the FP. It was because of the negative genetic correlations (caused by pleiotropic or linked genes) between TMY and FP and also between TMY and PP which generally about -0.30 to -0.50 (Gaidarsca et al., 2004; Toghiani, 2012). Previous study by Muladno and Astuti (1985) in BPT Baturraden showed genetic and phenotypic correlations between TMY and FP were -0.76 and -0.26 , respectively. Negative correlation indcates a genetic antagonism between traits and its responsible genes for phenotypic expression (Kurnianto, 2009).

\section{Genetic Gain}

The genetic gain of TMY was 38.20 
$\mathrm{kg} /$ generation (Table 5) with $0.85 \%$ of selection effectivity. This realized selection response is in between the predicted responses by Hindratiningrum (2008) and Santosa et al. (2011), while the effectivity is lower. The generation interval was 3.92 years ( 3.68 years for female and 4.15 years for male), so that the annual genetic gain was $9.76 \mathrm{~kg}$. TMYs in BBPTU-HPT Baturraden fluctuated from year to year, possibly because the cow 006) and 5,004 kg in this present study, so that the rough average of progress rate was $11.2 \mathrm{~kg} /$ year (close to the result of this study). This genetic gain was much lower than those achieved by United States $(193 \mathrm{~kg})$, Netherlands $(131 \mathrm{~kg})$, Italy $(112 \mathrm{~kg})$ and $\mathrm{NZ}(43 \mathrm{~kg})$ (Sneddon et al., 2014). Higher genetic gain in NZ indicates that NZ cows and their offsprings actually have potential for greater genetic gain than their current achievement in Baturraden. The genetic gain was low because the imported dams and one generation after them took quite a long time to adapt to the local environment. This result was in agreement with Hammami et al. (2008) and Kiplagat et al. (2012) that the geneticenvironmental interaction can reduce the efficiency of genetic quality improvement.
FP and PP, as correlated selection responses, decreased by respectively $0.16 \%$ and $0.04 \%$ per generation or $0.04 \%$ and $0.01 \%$ per year (Table 5 ). Because of the medium to high negative correlation between TMY and FP, it is very difficult to improve TMY and FP simultaneously. The alternative method is applying selection based on FY. Genetic correlation between TMY and FY and between TMY and PY of dairy cows were reported positive from 0.44 to 0.95 (Gaidarsca et al., 2004; Toghiani, 2012). Genetic correlation between FY and PY was from 0.60 to 0.76 so that the selection based on FY also be expected to increase PY.

TMY-based selection resulted in higher TMY response than FY-based selection, but with lower FP (Table 6 and Table 7). If assumed that each $0.1 \%$ of increased FP above $3.5 \%$ will gain additional sale price, selection based on FY is more profitable. Selection based on FY with $80 \%$ selected dams is expected to increase FY by 1.35 $\mathrm{kg} /$ year. Predicted genetic gain in NZ was higher than this value $(2.22 \mathrm{~kg} /$ year $)$. FP and PP will be increase from $4.96 \%$ to $4.97 \%$ and $3.78 \%$ to $3.82 \%$, respectively, in 10 years (Sneddon et al., 2014). It can be seen that although TMY and FP

Table 6. Predicted Response to Selection Based on Total Milk Yield

\begin{tabular}{|c|c|c|c|c|c|c|}
\hline \multirow{2}{*}{ Proportion } & \multirow{2}{*}{$\Delta \mathrm{G}_{\mathrm{TMY}}$} & \multirow{2}{*}{$\bar{A}_{\mathrm{TMY}}$} & \multicolumn{2}{|c|}{ Correlated Responses } & \multirow{2}{*}{$\bar{A}_{\mathrm{FY}}^{-}$} & \multirow{2}{*}{$\bar{A}_{\mathrm{FP}}$} \\
\hline & & & $\Delta \mathrm{G}_{\mathrm{FY}}$ & $\Delta \mathrm{G}_{\mathrm{FP}}$ & & \\
\hline & ............. & $\ldots . .(\mathrm{kg}) \ldots \ldots$ & ........... & $\ldots .(\%) \ldots$ & $\ldots(\mathrm{kg}) \ldots$ &..$(\%)$. \\
\hline $10 \%$ & 278.11 & $5,094.37$ & 14.84 & -0.10 & 238.46 & 4.54 \\
\hline $20 \%$ & 229.28 & $5,045.55$ & 13.99 & -0.08 & 237.61 & 4.56 \\
\hline $30 \%$ & 198.21 & $5,014.48$ & 12.28 & -0.05 & 235.90 & 4.59 \\
\hline $40 \%$ & 168.58 & $4,984.85$ & 11.44 & -0.03 & 235.06 & 4.61 \\
\hline $50 \%$ & 140.55 & $4,956.82$ & 9.03 & -0.03 & 232.65 & 4.61 \\
\hline $60 \%$ & 116.18 & $4,932.45$ & 8.14 & -0.02 & 231.76 & 4.62 \\
\hline $70 \%$ & 90.70 & $4,906.96$ & 6.77 & -0.01 & 230.39 & 4.63 \\
\hline $80 \%$ & 63.52 & $4,879.78$ & 4.39 & -0.01 & 228.01 & 4.63 \\
\hline $90 \%$ & 35.09 & $4,851.35$ & 2.56 & 0.00 & 226.18 & 4.64 \\
\hline
\end{tabular}

Note for Table 6-7. $\Delta \mathrm{G}=$ predicted selection response; $A=$ predicted performance of daughters population; average performances of initial dam population were 4,816.26 kg for TMY, $223.62 \mathrm{~kg}$ for FY and $4.64 \%$ of FP. Estimated $\mathrm{h}^{2}$ was based on the result of this study (Table 1). 
Table 7. Predicted Response to Selection Based on Milk Fat Yield

\begin{tabular}{|c|c|c|c|c|c|c|}
\hline \multirow[b]{2}{*}{ Proportion } & \multirow[b]{2}{*}{$\Delta \mathrm{G}_{\mathrm{FY}}$} & \multirow[b]{2}{*}{$\overline{\mathrm{A}}_{\mathrm{FY}}$} & \multicolumn{2}{|c|}{ Correlated Responses } & \multirow{2}{*}{$\bar{A}_{\mathrm{TMY}}$} & \multirow{2}{*}{$\bar{A}_{\mathrm{FP}}$} \\
\hline & & & $\Delta \mathrm{G}_{\mathrm{TMY}}$ & $\Delta \mathrm{G}_{\mathrm{FP}}$ & & \\
\hline & ............ & $\ldots(\mathrm{kg}) \ldots$. & 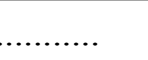 & $\ldots(\%) \ldots$ & $\ldots(\mathrm{kg}) \ldots$ & $\ldots .(\%) .$. \\
\hline $10 \%$ & 22.84 & 246.46 & 187.00 & 0.29 & $5,003.26$ & 4.93 \\
\hline $20 \%$ & 18.98 & 242.60 & 171.68 & 0.22 & $4,987.95$ & 4.86 \\
\hline $30 \%$ & 16.05 & 239.67 & 153.94 & 0.18 & $4,970.21$ & 4.82 \\
\hline $40 \%$ & 13.61 & 237.23 & 134.70 & 0.15 & $4,950.96$ & 4.79 \\
\hline $50 \%$ & 11.49 & 235.11 & 113.36 & 0.12 & $4,929.62$ & 4.77 \\
\hline $60 \%$ & 9.47 & 233.09 & 100.23 & 0.09 & $4,916.50$ & 4.74 \\
\hline $70 \%$ & 7.48 & 231.10 & 79.16 & 0.07 & $4,895.43$ & 4.72 \\
\hline $80 \%$ & 5.28 & 228.90 & 53.51 & 0.05 & $4,869.78$ & 4.70 \\
\hline $90 \%$ & 2.92 & 226.54 & 28.71 & 0.04 & $4,844.98$ & 4.68 \\
\hline
\end{tabular}

or PP have antagonistic correlations, FP and PP are still can be improved. It is because NZ consider FY and PY in their breeding worth selection index.

\section{CONCLUSION}

In BBPTU-HPT Baturraden, FP was highly heritable, while TMY, PP, FY and PY were moderately heritable. Selection for higher TMY only, negatively affect FP and PP. Selection can be applied based on FY to avoid these decreases. Negative effects of genetic-environmental interaction resulted in slower genetic gain because the imported dams and one generation after them needed time to adapt to the local environment. Adaptive cows $\left(\mathrm{G}_{2}\right.$ and the next generations) are recommended to be further selected with high EBV of sires are also considered.

\section{ACKNOWLEDGMENT}

This study was fully financed by Indonesia Endowment Fund for Education (Lembaga Pengelola Dana Pendidikan / LPDP) through Master Scholarship Program. The authors would like to thank Head of BBPTU-HPT Baturraden for allowing the study and his staffs (especially Head of Information Section) for gathering data.

\section{REFERENCES}

Ayalew, W., B. Rischkowsky, J.M. King and E. Bruns. 2003. Crossbreed did not generate more net benefits than indigenous goats in Ethiopian smallholdings. Agric. Systems. 76:1137-1156

Badan Pusat Statistik. 2015. Populasi Ternak. http://www.bps.go.id. [Accessed February $15,2015]$.

Berry, D.P., M.L. Bermingham, M. Good and S.J More. 2011. Genetics of animal health and disease in cattle. Irish Vet. J. 64:5

Bohlouli, M. and S. Alijani. 2012. Genotype by environment interaction for milk production traits in Iranian Holstein dairy cattle using random regression model. Livest. Res. Rural Dev. 24(11):120-124

Cassell, B. 2009. Using Heritability for Genetic Improvement. Virginia Tech, Virginia Cooperative Extension and State University, Virginia.

Direktorat Jenderal Peternakan dan Kesehatan Hewan. 2013. Statistik Peternakan dan Kesehatan Hewan 2013. Kementerian Pertanian RI, Jakarta.

Gaidarsca, V., N. Rusev and Y. Popova. 2004. 
Correlation between the breeding indicators of black and white cows in Bulgaria. Biotechnol. Anim. Husb. 20(1-2):17-21

Gantner, V., P. Mijić, K. Kuterovac, D. Solić and R. Gantner. 2011. Temperature-humidity index values and their significance on the daily production of dairy cattle. Mljekarstvo. 61(1):56-63

Hammami, H., B. Rekik, H. Soyeurt, A. B. Gara and N. Gengler. 2008. Genetic parameters for Tunisian Holsteins using a test-day random regression model. J. Dairy. Sci. 91:2118-2126

Harris, B.L., J.E. Pryce, Z.Z. Zu and W.A. Montgomerie. 2006. Development of new fertility breeding values in the dairy industry. N.Z. Soc. Anim. Prod. 66:107-112

Hindratiningrum, N. 2008. Respon dan efektivitas seleksi individu sapi perah yang ditaksir menggunakan catatan produksi individu dan tetua betinanya. J. Ilmiah Inkoma. 19(1):1-9

Kamayanti, Y., A. Anggraeni and Pallawarukka. 2006. Pemeriksaan interaksi genetik dan lingkungan dari daya pewarisan produksi susu pejantan Friesian-Holstein impor yang dipakai sebagai sumber bibit pada perkawinan IB. Proceedings. Lokakarya Nasional Pengelolaan dan Perlindungan Sumber Daya Genetik di Indonesia: Manfaat Ekonomi untuk Mewujudkan Ketahanan Nasional, Bogor, Indonesia, December 20, 2006. P. 175-181.

Karnaen and J. Arifin. 2009. Korelasi nilai pemuliaan produksi susu sapi perah berdasarkan test day laktasi 1, laktasi 2, laktasi 3, dengan gabungannya. Anim. Prod. 11(2):135-142

Kiplagat, S.K., I.S. Kosgey and M.K. Limo. 2012. Genetic Improvement of Livestock for Milk Production. In: Milk Production - Advanced Genetic Traits, Cellular Mechanism, Animal Management and Health (N. Chaiyabutr, ed.). Intech Publishers, Rijeka. P. 77-96.

Kurnianto, E. 2009. Pemuliaan Ternak. CV. Graha Ilmu, Yogyakarta.

Kurniawati, D., H. Mulyadi and Adiarto. 2013. Heritability value of milk production of Holstein Friesian imported from New Zealand at Baturraden, Banyumas. Proceedings. The $6^{\text {th }}$ Conference of Indonesia Students Association in Korea, Daejeon, Korea, July 7, 2013. CISAK 2013$\mathrm{C} 6 / \mathrm{O} / 70$.

Lal, A., T. Ikeda, N. French, M. G. Baker and S.
Hales. 2013. Climate variability, weather and enteric disease incidence in New Zealand: time series analysis. Plos One. 8(12):e83484.

Lopez-Villalobos, N. 2012. Analysing the genetic basis of milk production traits. CAB Rev. $7: 1-18$

Mirkena, T., G. Duguma, A. Haile, M. Tibbo, A. M. Okeyo, M. Wurzinger and J. Sölkner. 2010. Genetics of adaptation in domestic farm animals: a review. Livest. Sci. 132:1-12.

Muladno and M. Astuti. 1985. Korelasi fenotipa dan genotipa antara produksi susu dengan kadar lemak susu sapi Fries Holland di Balai Pembibitan Ternak Baturraden. Media Peternakan. 10(3):39-55

Ojango, J.M. and G.E. Pollott. 2001. Genetics of milk yield and fertility traits in HolsteinFriesian cattle on large-scale Kenyan farms. J Anim. Sci. 79:1742-1750

Radke, B.R. 2000. Profitable culling and replacement strategies. Adv. Dairy Technol. 12:245-256

Santosa, S.A., A.T.A. Sudewo and A. Susanto. 2014. Penyusunan faktor koreksi produksi susu sapi perah. Agripet. 14(1):1-5

Santosa, S.A., A.T.A. Sudewo, A. Susanto and Iswoyo. 2011. Response, effectiveness and accuracy of different selection methods and intensities in dairy cattle. Anim. Prod. 11(1):66-70

Sawa, A., M. Bogucki, S. Krężel-Czopek, and W. Neja. 2013. Relationship between conformation traits and lifetime production efficiency of cows. ISRN Vet. Sci. 2013:124690

Sneddon, N.W., N. Lopez-Villalobos, R.E. Hickson, L. Shalloo, D.J. Garrick and U. Geary. 2014. Prediction of industry production of milk components, yields of dairy products and lactose deficit under the current breeding objective of New Zealand dairy cattle. Proceedings. The $10 \mathrm{t}^{\mathrm{h}}$ World Congress of Genetics Applied to Livestock Production, Vancouver, BC, Canada, August 17-22, 2014. Poster code \#398.

Toghiani, S. 2012. Genetic relationships between production traits and reproductive performance in Holstein dairy cows. Archiv. Tierzucht. 55(5):458-468.

Zanton, G. I. and A. J. Heinrichs. 2005. Metaanalysis to assess effect of prepubertal average daily gain of Holstein heifers on first lactation production. J. Dairy Sci. 88:38603867 